\title{
LOS TRABAJOS DEL MITO CLÁSICO EN EL CHILE CONTEMPORÁNEO: LA PUTA MADRE de Marco Antonio de la Parra
}

The labors of classical myth in contemporary Chile: La puta madre of Marco Antonio de la Parra

\author{
MARIA MORANT GINER \\ UNIVERSITAT DE VALÈNCIA (ESPAÑA) \\ Mamogi4@alumni.uv.es http:/ /orcid.org/0000-0003-3569-4551
}

RECIBIDO: 4 DE SEPTIEMBRE DE 2019 ACEPTADO: 28 DE OCTUBRE DE 2019.

RESUMEN: En la actualidad la preocupación por la memoria ha llegado a ocupar un lugar central en la vida política y cultural, especialmente en aquellas sociedades que se encuentran en procesos de justicia transicional o sumida en luchas por los derechos humanos. Este es el caso del Chile postdictatorial que desde el fin de la dictadura en 1989 ha vivido diferentes ciclos e intensidades de luchas políticas por la memoria. Muchos han sido los estudios que se han realizado sobre estas pugnas por establecer los sentidos del pasado, especialmente desde los campos de la sociología o los estudios culturales. En nuestro caso, proponemos un acercamiento desde los estudios de tradición clásica con el fin de poder establecer a qué finalidad responde el uso del mito clásico en la reinterpretación del pasado nacional. Para ello, se ha realizado el análisis de La puta madre (1998) de Marco Antonio de la Parra, un drama que reescribe el mito de los Atridas y lo adapta al contexto social y cultural del Chile de la segunda mitad del siglo XX para poner en escena tensiones, contradicciones y ansiedades propias de la cultura de la memoria presente.

PALABRAS ClaVE: Chile, postdictadura, memoria, teatro, mito clásico.

ABSTRACT: At this moment, concern about the memory takes up the center in the political and cultural life in many countries. It is the case of Chile, which since 1989 it has lived through many political disputes for memory. The sociology and cultural studies have done many researches about this problema. In this study we have taken the perspective of the classical tradition with the aim of reflecting the use of classical myth in the reinterpretation of the national past. For this we have analyzed La puta madre (1998), a play inspired by the legend of the Atreus and adapted to the social and cultural chilean context of the second half of the 20th century to dramatize tensions, contradictions and anxieties of the current culture of memory.

KEYWORDS: Chile, post-dictatorship, memory, theatre, classical myth. 


\section{UN LENGUAJE DRAMÁTICO PARA LA CATÁSTROFE}

APOLO: Nadie soporta acordarse de todo. Nadie soporta mirar hacia atrás. Todos quieren mirar el futuro. Después ya es tarde. Reemplazas la memoria por el deseo y quedas vacío. La puta madre, Marco Antonio de la Parra

La amnesia voluntaria de la que habla el dios Apolo, la memoria entendida como olvido o la llegada de una sociedad de consumo gobernada por el deseo y absolutamente despolitizada, son algunas de las cuestiones que Marco Antonio de la Parra dramatiza en La puta madre, su particular reescritura del mito de los Atridas. Estas son preocupaciones que han llegado a ocupar un lugar central en la vida política y cultural, especialmente en aquellas sociedades que se encuentran en procesos de justicia transicional o sumidas en luchas por los derechos humanos (Jelin, 2002). Es el caso del Chile postdictatorial que desde el fin de la dictadura en 1989 ha vivido diferentes ciclos e intensidades de luchas políticas por la memoria. Estas pugnas por establecer los sentidos del pasado se han estudiado de forma sistemática, especialmente desde los campos de la sociología (Halbwachs, 1950; Nora, 1984; Gatti, 2011) o los estudios culturales (Longoni, 2006; Richard, 2007; Feld, 2016). En este trabajo, proponemos un acercamiento desde los estudios de tradición clásica, a partir de una cuestión fundamental: ¿de qué forma puede actualizarse un texto clásico para dar cuenta de procesos y experiencias que tienen que ver con nuestro presente y nuestro pasado reciente?

En base a este propósito, hemos centrado la presente investigación en un doble eje: el diálogo del teatro con las luchas por la memoria de la postdictadura chilena y la función del mito clásico en estas pugnas. Para responder a estas cuestiones hemos analizado La puta madre, obra en la que Marco Antonio de la Parra recurre al caudal de la tragedia griega para dramatizar y poner en escena tensiones, contradicciones y ansiedades propias de la cultura de la memoria presente.

En los primeros años del retorno a la democracia, en Chile, no existían espacios, ni en las políticas de la memoria ni en los medios de comunicación, donde dialogar y reflexionar sobre los efectos de la dictadura pinochetista. Pese a que se evitaba a toda costa la representación de los actores sociales enfrentados en los medios de comunicación y en los lugares públicos, hubo tentativas de esta escenificación en otros espacios artísticos, de menor alcance, como el teatro, donde se dramatizaron los vacíos y silencios impuestos por el pacto de la Concertación al pasado reciente chileno. En este contexto, cobra especial relevancia la capacidad del teatro de hacer presente la ausencia y traerla de nuevo a nuestra memoria, lo que implica sacar a la luz aquellos sucesos que habían sido vedados y oscurecidos primero por la dictadura y más tarde por la política de reconciliación de los gobiernos democráticos (Núñez, 2013: 52).

El teatro permite, pues, articular una memoria relacionada intrínsecamente con la justicia, que permanecía ausente en las políticas de la memoria. El dramaturgo en su pretensión de repensar el pasado realiza dos gestos fundamentales que ponen el hecho teatral en relación con los trabajos de la memoria. Por un lado, escenifica un discurso de verdad que puede entrar en disputa con otras memorias o versiones oficiales y tomar parte del debate nacional acerca de la función de la violencia y sus sentidos político e histórico. Por otro lado, pone en marcha una tentativa de duelo mediante "las representaciones y figuraciones de los objetos de la pérdida y de 
los dispositivos represivos a través de los cuales estas pérdidas han tenido lugar" (Peris, 2005: 168). Proponemos, por ello, pensar el hecho teatral como un "escenario de la memoria" (Feld, 2016) en el que se entrecruzan dos de los principios fundamentales del trabajo de la memoria: la distancia temporal con el pasado y la construcción de una verdad. En estos escenarios tiene lugar la puesta en escena, mediante el lenguaje y elementos adecuados, de un relato veritativo que entra en lucha con otras verdades y versiones de la historia (Feld, 2016: 79).

Esta tendencia teatral (que perdura a día de hoy) se inició durante la dictadura, bajo una gama muy heterogénea de obras que convergían al oponerse a la ideología fascista del régimen militar enalteciendo como valor ético la memoria, entendida esta como "recuperación de una experiencia común, como posibilidad de justicia [...] como un dispositivo de resistencia al olvido o al borramiento del acontecimiento del golpe" (Núñez, 2013: 44). Pese a la heterogeneidad de voces y propuestas que se refunden en este bloque, todas ellas toman cuerpo a partir de la tensión entre el "imperativo de contar" y la "imposibilidad de contar", de plasmar en palabras o imágenes la experiencia vivida, ya que no existe un lenguaje adecuado para hacerlo. Esta escenificación de la memoria que pretendemos estudiar se articula a partir de la tentativa y ensayo de diferentes poéticas de la memoria (entendidas como "lenguajes para hablar del desastre", Paladini, 2007: 5) que reinventan un lenguaje capaz de dar cuenta de la memoria del trauma.

Estas propuestas estéticas parten de la búsqueda de formas narrativas que puedan dar cuenta de la catástrofe de la violencia política, para incorporar en la práctica artística lo rehusado, lo negado, lo olvidado por los relatos de autoridad y sus narraciones hegemónicas (Paladini, 2007: 20). Para ello hay que explorar y sacar a la luz las fisuras y los quiebres producidos en la subjetividad, trabajar con los daños presentes en las capas internas más profundas del yo (Hurtado, 2000: 61). Se busca, por tanto, reinventar un lenguaje capaz de dar cuenta de la memoria del trauma (Paladini, 2007: 20).

Si el trabajo de la memoria implica armar una historia sobre una experiencia negada y silenciada (Rojas, 2000: 184), el dramaturgo debe enfrentarse a la problemática de dar cuerpo y voz a los cuerpos violentados y desaparecidos. ¿Cómo representar la tortura y la desaparición forzada? Ante la falta de palabras, de códigos dramáticos, se ensayan diversas fórmulas que tratan de violentar el lenguaje escénico, las estructuras dramáticas y el concepto mismo de obra para dar cuenta del impacto de la violencia de estado en la subjetividad y en lo social. La representación del cuerpo violentado de la tortura, del cuerpo desparecido de los desaparecidos y, en definitiva, del impacto que la violencia de Estado produjo en la sensibilidad y subjetividad de los chilenos, serán una constante en aquellas obras que se proponen repensar los hechos pasados para poder reescribirlos e insertarlos en la memoria social.

2. El mito Clásico en el teatro Chileno: LA PUTA Madre de Marco ANTONio de la PARRA

En América Latina el interés por la tragedia griega surgió en los siglos XVIII y XIX cuando los intelectuales descubrieron las posibilidades que ofrecía esta como herramienta educativa, como instrumento político dirigido a construir y consolidar la identidad latinoamericana. En plena ebullición de los nacionalismos, se escribieron muchas tragedias de tema local indigenista, no obstante, paralelamente despuntaron algunas de tema griego y romano como Virginia (1824) 
de Domingo Navas Spínola o Sacrificio de Idomeneo (1803) de Jose María Salazar. Estas obras adelantaron ya el uso de motivos clásicos para la denuncia del tirano, encarnado en la monarquía española que impedía la fundación de las nuevas repúblicas americanas independientes (Hualde, 2012: 188).

El afán por la recreación de argumentos míticos grecolatinos alcanza su momento cumbre a mediados del siglo XX, "coincidiendo con la toma de conciencia de las difíciles situaciones políticas de los diversos países" (Hualde, 2012: 191). En estas reescrituras contemporáneas es común el entrecruzamiento del tiempo mítico con la historia actual, la transposición de personajes o situaciones míticas a la realidad del momento, con el fin de evidenciar la universalidad y reiteración de los conflictos humanos. No se prioriza ya la imitatio precisa de los modelos y referentes clásicos. Debemos entender la reutilización del mito como un lenguaje estético, escogido por el dramaturgo para reflejar su visión del mundo. Ante las divergencias que plantean las nuevas actualizaciones respecto al material mítico tradicional, la labor del estudioso no es ya tanto comparativa (búsqueda de similitudes o diferencias) sino más bien de reflexión acerca de los cambios y transformaciones políticas, económicas, culturales y sociales a las que apuntan.

En algunos casos, la manipulación y transposición del mito al contexto actual difumina y dificulta el reconocimiento de las fuentes. Por ello, el título es importante para el reconocimiento de los juegos intertextuales: "nos señala las reglas del juego y nos hace estar alerta a otras posibilidades" (Hutcheon, 1993: 199). En el caso de De la Parra el subtítulo ("La Orestíada de Chile: tragedia griega sin griegos, Orestíada sin Orestes") contiene la clave de interpretación y no solo esto, sino que también adelanta la modificación del desenlace de la trama: en esta pieza no tendrá lugar la venganza de Orestes.

\subsection{El mito Clásico en la obra de Marco ANTONio de la Parra}

Marco Antonio de la Parra es una de las grandes figuras del teatro chileno contemporáneo. Se introdujo en el mundo del teatro mientras cursaba medicina en la Universidad de Chile. Su especialización en psiquiatría le ha facilitado la adopción de una perspectiva crítica de la patología social, política y sexual de la sociedad (Pérez-Laborde, 2010:109). Aunque es uno de los dramaturgos más reputados de la postdictadura no debemos olvidar que su andanza teatral comenzó durante la dictadura, cuando se convirtió en la voz culta y punzante de la disidencia gracias a obras como Lo crudo, lo cocido, lo podrido (1978) o La secreta obscenidad de cada día (1984).

Forma parte de la primera generación de artistas chilenos que, tras el apagón cultural provocado por la dictadura, "logró articular un heterogéneo coro de voces críticas -disidentes, resistentes, contestatarias o refractarias- al gobierno militar" (Pérez-Laborde, 2010: 112). Este contexto, aparentemente adverso para la creación y el desarrollo artístico, favoreció la experimentación lúdica con nuevos lenguajes basados en la metáfora o el símbolo para dar cuenta del colapso de los proyectos históricos individuales y colectivos, la frustración o la desesperanza frente al futuro (Albornoz, 2006: 113). Esto supuso un cambio, un distanciamiento respecto al realismo con pretensión mimética que había monopolizado el teatro chileno desde sus inicios. Esta generación posgolpe introdujo elementos del absurdo, poesía, mito, grotesco e ironía y 
contribuyó a renovar la escena chilena (Pérez-Laborde, 2010: 53). El mismo dramaturgo confiesa que la dictadura le obligó a "crear lenguajes para lo que ella misma prohibía, obligaba al espacio posible a volverse depositario de lo irrepresentable" (De la Parra, 1997: 36).

Una vez finalizada la dictadura abandonó paulatinamente ese lenguaje teatral en favor de un crudo lirismo que diese cuenta del desgarro subjetivo e identitario que provocó la represión militar en los chilenos y como el ansiado retorno a la democracia "era una mala versión de lo deseado" (Albornoz, 2006: 122). Durante este periodo de apertura cultural, mantuvo una posición crítica respecto al proceso de redemocratización que se había iniciado en el país el 11 de marzo de 1990, capitaneado por la Concertación.

En estos años incrementó el diálogo intertextual en sus obras, un recurso que durante la etapa de dictadura había favorecido la evasión de la censura. De la Parra retoma estos juegos intertextuales con la pretensión de denunciar cómo los textos clásicos, dirigidos y adaptados actualmente para un público masivo, han sido transformados en pastiches kitsch y obras neobarrocas (Albornoz, 2006: 119). En este contexto surgen sus primeras reescrituras de textos grecolatinos: Dédalus en el vientre de la bestia o Dédalus/ Subámerica (1992) y Telémaco/ Subeuropa o El padre ausente (1993). Su relación con los mitos no es siempre reivindicativa, de elogio o de admiración, sino que en muchos casos procede a su desmitificación y desautomatización porque en la sociedad actual moderna ya no hay lugar para las grandes historias (Aelbrecht, 2016: 8). Por ello, cuando reelabora tragedias griegas, adapta sus tramas y constituyentes al mundo actual, generando en ocasiones un efecto de parodia del héroe clásico.

En las siguientes páginas ofrecemos nuestra interpretación de La puta madre (1998), obra en la que, a la vez que reescribe su particular visión del mito de los Atridas, reflexiona sobre la historia, memoria e identidad chilena. En ella se cuestiona acerca de cómo tratar el pasado reciente (¿con silencio, con olvido, con memoria?) y el impacto que la dictadura y el neoliberalismo causan sobre la subjetividad de los chilenos, aspectos que son explorados una y otra vez a lo largo de su producción.

La puta madre fue escrita en 1997 y estrenada en 1998 en la IV Muestra de Dramaturgia Nacional, bajo la dirección de Viviana Steiner. En dicho certamen se alzó con el primer premio y, posteriormente, en el año 2000 fue nominada al Premio Altazor de Dramaturgia. Desde entonces, ha sido representada por diversas compañías en distintos puntos del país con excelentes críticas. Destacan, en la última década, los montajes de Ana Vallejo (2006 y 2007), Daniel Lattus (2008 y 2009) y la puesta en escena de los estudiantes de la ENAD en 2018.

La obra ha sido publicada bajo distintos títulos: "LA TIERRA INSOMNE o también LA ORESTÍADA de CHILE (tragedia griega sin griegos, Orestíada sin Orestes) o más propiamente conocida como LA PUTA MADRE o igualmente LA MADRE PATRIA" (1). Estas variantes reflejan la ansiedad de condensar distintos temas, de señalar los elementos principales del texto. Estos son: la intertextualidad griega y la memoria e identidad chilena. Estos posibles títulos son intercambiables entre sí y contienen las claves de posibles interpretaciones. De este modo, indica 
que va a escenificar la historia de Chile ("la madre patria") simbolizada en la figura mítica de Cassandra ("la puta madre").

La obra se compone de una yuxtaposición de 21 escenas que reflejan momentos anteriores a la implantación del régimen militar, durante la vigencia de este o tras su caída. Aparentemente no hay un hilo lógico-causal que enlace estas escenas, sino saltos temporales que nos mostrarán el impacto de la dictadura en una familia socialista. A partir de los distintos actos es posible reconstruir la intrahistoria familiar y una memoria alternativa a la impulsada por la Concertación.

\subsection{NUEVAS COORDENADAS GEOTEMPORALES PARA LA LEYENDA DE LO ATRIDAS}

Esto no sucede en Grecia. El escenario está vacío y es sudamericano, pero del fin de siglo, es decir, ninguna parte. Tal vez las ruinas de un Centro Comercial o la feísima entrada de un estacionamiento subterráneo. Al fondo, bolsas que parecen contener cadáveres como las que se usan para recoger los restos de una catástrofe. Llenas. (2006: 1)

Estas indicaciones que abren la obra son realmente significativas por diversas razones. En primer lugar, como nos adelanta el subtítulo, esta tragedia no va a suceder ni en tierras griegas ni está protagonizada por héroes griegos. Las coordenadas geotemporales del mito de los Atridas han sido modificadas: nos situamos en algún lugar del continente latinoamericano a finales de siglo. El tiempo es cercano al espectador, las paradas de metro y los centros comerciales forman ya parte del paisaje urbano. Bastan pocas palabras para que De la Parra, de un modo tan visual, ponga ante el espectador o lector las claves para entender las transformaciones que han dado lugar al Nuevo Chile (Moulian, 1997). En esta escena, si relacionamos las bolsas de cadáveres con el régimen militar y el centro comercial con el mercado neoliberal, podemos afirmar que de la Parra ofrece un correlato visual de las palabras de Moulian:

Chile Actual proviene de la fertilidad de un "ménage a trois", es la materialización de una cópula incesante entre militares, intelectuales neoliberales y empresarios nacionales o transnacionales. [...] Esa tríada realizó la revolución capitalista, construyó esta sociedad de mercados desregulados, de indiferencia política, de individuos competitivos realizados o bien compensados a través del placer de consumir o más bien de exhibirse consumiendo, de asalariados socializados en el disciplinamiento y en la evasión. En la Matriz de una dictadura terrorista devenida dictadura constitucional se formó Chile Actual, obsesionado por el olvido de esos orígenes. (1997: 18)

De la Parra pone el broche a esta metáfora que descubre el origen del neoliberalismo con la falta de concreción respecto al espacio. Si bien la acción es situada en Chile por el mismo autor en el subtítulo, este "escenario vacío sudamericano" da cobijo a cualquier región del hemisferio sur. Que la instauración del neoliberalismo en gran parte de Latinoamérica vino de la mano de los golpes de estado de los militares es algo que Klein señalaría posteriormente en La doctrina del shock (2007).

\footnotetext{
1 De la Parra opta por transcribir los antropónimos de los protagonistas como "Cassandra" y "Agamenon" frente a las variantes onomásticas más comunes de la tradición: "Casandra" y "Agamenón”. Con estos últimos nos referiremos a los personajes míticos, mientras que "Cassandra" y "Agamenon" se emplearán para referirnos a los personajes de La puta madre.
} 
En este panorama desolador el Niño toma la palabra para hablar de su madre, Cassandra: esa mujer que está loca, que no puede dormir y toma píldoras para hacerlo, de quien se dice que un dios le otorgó el poder de la adivinación. Este personaje abre y cierra la obra y con sus preguntas acerca de la historia familiar provoca flashbacks y hace avanzar la acción dramática. Pregunta a su progenitora por su padre, cómo le conoció, cómo se enamoraron, y, de este modo, mediante un juego de analepsis y prolepsis, vamos conociendo la historia de Cassandra, "la puta madre" que se corresponde con la de "la madre patria". Del mismo modo que le sucedió a Chile, Cassandra va a ser arrasada, vejada por las Fuerzas Armadas. Este paralelismo fue apuntado por Aelbrecht: "Cassandra, como el país, sufre la violencia: ella está violada y torturada, como la tierra es brutalizada y violada en sus principios democráticos” (2016: 45).

En la escena 2 se produce el primer salto al pasado, al momento en que se está gestando una Revolución, que, a tenor de las palabras del padre, presenta un marcado carácter socialista: "PADRE: ¿Oíste Casandra? Todos están muy contentos. Trabajo para todos, comida para todos, igualdad para todos, educación para todos" (2006: 4). El triunfo de dicha Revolución, en la que también participó el Hermano de Cassandra como militante, no tardará en celebrarse:

PADRE: Miren las manos obreras. Miren los brazos obreros. Lo logramos. El país entero salta de gozo. No hay vuelta que darle, tenemos el poder [...] Este es el día de la Liberación. Este es el día en que dejamos de estar sometidos, de tener miedo. La tierra será de quien la trabaja, las fábricas de los obreros, el futuro de nuestros hijos. No habrá más desigualdad, no habrá más injusticias. [...] La tragedia queda declarada imposible. (2006: 8)

Esta última sentencia avanza la ironía trágica que está por venir. La joven, por este don de la adivinación que hemos mencionado, no puede compartir la alegría familiar ${ }^{2}$. En sus visiones aparecen "helicópteros, aviones, tropas desfilando, cuerpos arrastrados por las aguas" (2006: 7), augurando la tragedia que se avecina, la que su padre declara imposible.

Pese a que aquí se habla de una "Revolución", no podemos evitar establecer paralelismos con la implantación de un gobierno socialista en Chile, aunque este fuese elegido democráticamente. El posterior golpe de Estado (representado aquí en las visiones de Cassandra) interrumpió la evolución de este proyecto socialista que ponía en peligro el dominio de los sectores conservadores: la élite económica había perdido la exclusividad en su poder de decisión en materias de políticas públicas, por tanto, no podía velar ya por sus propios intereses. Este sector que veía peligrar su supremacía política, incapaz de regular el conflicto político, instó a intervenir a las Fuerzas Armadas. Lo que sucedió después forma parte de los anales de la historia: una vez dado el golpe, el general Pinochet, para sorpresa de los partidos conservadores, se reafirmó en su voluntad de gobernar solo.

\footnotetext{
2 “CASANDRA: Todo va a salir mal. Lo sé. Lo he soñado. Lo he visto. No quiero que lo maten” (2006: 5).

Aelbrechet (2016: 45) considera que el desagrado del Padre ante las profecías de Cassandra es equiparable al rechazo que estas visiones ocasionarían en el público durante la representación, ya que en ellas se mencionaba ese pasado que nadie quería escuchar.
} 
En nuestra obra los bombardeos ${ }^{3}$ ponen fin al proyecto social impulsado por la Revolución y se instaura un gobierno militar, personificado, en nuestro caso, en la figura de Agamenon. Se produce, tras el golpe, la dispersión familiar e iremos conociendo poco a poco el destino que aguarda a los distintos personajes.

\subsection{CASSANDRA: REESCRITURA DE LA FIGURA DE LA COLABORADORA}

La protagonista de esta obra es, sin duda, Cassandra, la puta madre. Marco Antonio de la Parra funde el personaje mítico de Casandra, la princesa troyana, con el tópico de la colaboradora, convertido en los últimos años en símbolo de la postdictadura y la transición chilena. Cassandra es la hija menor de una familia socialista y, tras el golpe militar, es recluida en un campo de detención. Allí se produce la transformación subjetiva del personaje gracias al proceso de disciplinamiento al que es sometida, sufre la evolución de loca $>$ colaboradora $>$ consumidora. Recordemos que la historia de Cassandra simboliza la historia de Chile, por tanto, nos habla metafóricamente de la transformación que ha dado lugar al Chile actual.

En su primera intervención ella misma confirma que escucha voces y le persiguen sombras que no le dejan dormir, que consume píldoras que le facilitan el descanso ${ }^{4}$. Es tratada de loca por su entorno familiar, sus fúnebres previsiones chocan con la alegría familiar ante el cercano triunfo de la Revolución ${ }^{5}$ y genera su rechazo. La joven se encuentra en un estado de alienación debido a las visiones que la perturban, sabe que a la Revolución le sigue la catástrofe y por ella reniega del combate armado en el que se embarcan el Padre y el Hermano.

Sin embargo, este motivo de la locura, presente ya en la Casandra mítica, ¿funciona aquí como el castigo del dios Apolo, quien tras regalarle el don de la adivinación la condenó a no ser creída por nadie? Es cierto que De la Parra hace alusión a este episodio de raigambre mítica, pero conocemos también las posibilidades que ofrece la locura como metáfora de la falta de normalización social, que acompaña a los sujetos que no se pliegan a la estandarización impuesta. En el caso de Cassandra, se muestra ajena a la polarización que dividía la población en dos sectores ideológicamente opuestos: los que abogaban por un gobierno socialista y los inmovilistas que buscaban la perduración de una sociedad conservadora. Cassandra no es peligrosa para el nuevo régimen militar por ser militante de izquierdas o partidaria del socialismo, se convierte en persona non grata por esa lucidez que la lleva a rechazar todo tipo de conflicto armado. Esta falta de posicionamiento ideológico le vale la etiqueta de loca y el rechazo de ambos sectores, incluido

\footnotetext{
${ }^{3}$ El Piloto da cuenta del operativo desplegado: "PiLOto: Yo fui el que bombardeó el Palacio. Yo hice la operación perfecta. Yo debería tener una calle con mi nombre y una plaza con mi estatua. Ellos me dieron: vas a cumplir con tu patria, vas a salvarle del yugo extranjero" (2006: 23).

4 Quizás esta mención a los somníferos contenga una crítica velada a la mercantilización de la medicina a finales del siglo XX, el capitalismo permeabilizó en todas las esferas y la salud se incorporó al mercado como bien de consumo. Además, la medicina formaba parte de los procesos normalizadores y productores de sujetos saludables que pudiesen formar parte del sistema capitalista. En el caso de Cassandra podemos interpretar que el consumo de somníferos pone fin a sus profecías al concederle un plácido descanso sin visiones. De ser así, como hemos comentado, confirmaríamos el papel de la medicina en la normalización de sujetos alienados, marginados del sistema. 5 “PADRE [a Cassandra]: ¡No quieres la revolución! ¿Estás loca? Mi hija no puede ser reaccionaria” (2006: 5).
} 
el de sus familiares. Es un personaje, pues, que escapa a los marcos normativos en los que se establece el conflicto político en Chile.

Durante su detención se verá sometida a un proceso de adiestramiento basado en la tortura, cuyo fin será el de doblegar su subjetividad, hacerla más controlable por el poder y amoldarla a los cambios sociales que están por llegar. La joven cae en manos de militares y tras largas sesiones de tortura ${ }^{6}$ y vejaciones sexuales ${ }^{7}$ comienza a colaborar con las fuerzas armadas, a dar largas listas de nombres, cuyo paradero conoce gracias a su "don":

AgAmenon: Se ha pasado al bando nuestro. No soportó el dolor. Lo dijo todo. Nos ha prometido que dirá cada nombre, cada huella. Podremos saber dónde se esconden. Cuántos son. Nombres apellidos, direcciones. Amigos, enemigos. (p. 10)

Cassandra en esta obra no es solo una mujer torturada, sino que termina por convertirse en una delatora, una colaboradora. Esto nos permite explorar de forma detallada el "atroz derrumbe de la subjetividad como efecto de la aplicación continuada y racionalizada de un dolor corporal extremo y el modo en que la identidad individual de la detenida se vino a pique en las sesiones de tortura" (Peris, 2008: 152). Este flujo de información constante que entrega hace que su identidad anterior se derrumbe:

CASSANDRA: Ellos tienen la culpa. Me dejaron tonta de puro machacarme la cabeza. Pueden ver en ella los surcos trazados por sus dedos, tengo la garganta hecha hilachas de tanta corriente. Han dibujado en mi piel el mapa de la desgracia. Estoy peor viva que muerta (2006: 19).

De la Parra evidencia la relación directa que existe entre la aplicación de la violencia y los procesos de reconfiguración identitaria (Peris, 2008: 27). Esta violencia ejercida por los militares chilenos, durante un tiempo fue leída como una barbarie irracional o un exceso injustificable llevado a cabo a título individual por algunos subordinados, como concluye el Informe Rettig. Sin embargo, ocultaba un modo de producción que daba lugar a nuevas subjetividades mucho más moldeables e inclinadas hacia los intereses del poder político y militar. Esto se traduce en la emergencia de nuevos sujetos que, lejos de interesarse por tomar parte en la vida política, aceptan

\footnotetext{
${ }^{6}$ Aunque en ningún momento de la obra llega a escenificarse la tortura, la escena 15 transcurre tras una sesión de aplicación sistemática de la violencia (p. 22). Siguiendo el precepto de la tragedia griega de no escenificar actos violentos, De la Parra prescindió de escenificar la tortura estatal. Debemos pensar que quizás en 1998 esta cuestión era todavía irrepresentable, no se había construido todavía un lenguaje dramático capaz de escenificar la tortura, ni existía todavía un público preparado para enfrentarse de forma tan directa a estas cuestiones. Veamos cómo se construye esta escena 15:

"El cuerpo de Cassandra sobre una cama de metal sin colchón. Saltan chispas.

EGISTO: se nos pasó la mano.

AgAMENON: está viva.

EGISTO: no tiene un solo lugar por el que no sangre.

AgAmenon: Habla y no sabe que habla. Cree que es una víctima y es una más de nosotros. Hay un instante en el que el dolor se confunde con la crueldad. Ella quiere salvarse. Eso la perderá”.

7 Múltiples referencias a lo largo de la obra demuestran que el cuerpo femenino recibía un tratamiento especial frente al masculino en las sesiones de tortura, era visto como objeto sexual y por ello solía recibir altas dosis de violencia sexual:

"AgAMENON [a su hijo]: Yo no sé si soy tu padre. Tu madre fue recorrida por regimientos completos. La puta más loca. Prefirió entregarse a morir, prefirió delatar a sufrir" (p. 15).
} 
y se adaptan a los criterios impuestos por el mercado (Peris, 2008: 36), como le sucede a Cassandra.

El disciplinamiento es llevado a cabo con éxito: la joven deja de tener visiones y de anunciar el porvenir y, como consecuencia, deja de ser útil para los militares. Asistimos, simbólicamente, al paso de ciudadano a consumidor (Moulian, 1997: 104), como se observa en el último diálogo que tiene lugar entre Agamenon y Cassandra:

AGAMENON: ¿Qué hacemos contigo? ¿No has pensado en suicidarte?

CASSANDRA: prefiero comprarme un traje nuevo.

AGAMENON: ¿Y no te gustaría tener tu tienda propia?

CASSANDRA: Prefiero ir de compras.

La implantación del neoliberalismo por parte del régimen militar dio lugar a un nuevo individuo chileno, subordinado al mercado, disciplinado por el dinero (Moulian, 1997: 104). La violencia física repartida por el régimen militar, fue sustituida por una violencia estructural inherente a las leyes del mercado. El consumismo se convirtió en el nuevo dispositivo de control (Moulian, 1997: 107). Como Cassandra, gran parte de los chilenos dejaron que la sociedad de consumo reemplazara sus deseos y proyectos vitales por nuevos objetos de deseo, perdiendo así la propia identidad (Pinochet, 2012: 153). De este modo sobrevino la despolitización de la ciudadanía: la política deja de ser vista como posibilidad de deliberación crítica, ahora, el individuo aspiraba únicamente a ejercer sus derechos de consumidor.

Sin embargo, ¿por qué recurre al arquetipo de Casandra para reproducir la transformación subjetiva que se produce en el individuo tras la tortura? ¿Cuáles son los rasgos míticos que resultan funcionales a su propósito? Para su configuración De la Parra toma y altera una serie de rasgos presentes en los testimonios clásicos: Cassandra es tachada de loca por su entorno, que rechaza sus profecías y comenta su supuesto romance con un tal Apolo ${ }^{8}$. Siguiendo la versión de Licofrón, la joven es encerrada y aislada del mundo exterior, en este caso, en lugar de en una torre, en un CCD. Allí los militares explotan este don maldito que les permite localizar y detener a los militantes socialistas. De la Parra innova en su tratamiento y lo reviste de una ironía trágica doble: Cassandra no solo no consigue evitar la dispersión del núcleo familiar con sus advertencias, sino que será la responsable de la detención y muerte de su hermano, al colaborar con los militares y entregar su nombre9. Tras múltiples episodios de violencia (tortura y violación) por parte de los militares, es tomada por Agamenon como concubina, como si de un botín de guerra se tratase. Y, como sucede en Esquilo, pese a cohabitar en el mismo palacio que Agamenon y compartir su lecho, siempre será confinada a una posición de subalterna.

\footnotetext{
8 "CASSANDRA: Dicen que un dios me dió este don. Es falso. Que me calenté con él y él se calentó conmigo y de puro caliente me ofreció el don de la profecía. Y dicen que cómo no me acosté con él se picó y me maldijo. Nadie me haría caso" (p. 2). Sin embargo, Casandra le confiesa a su hermano más adelante que no se acostó con Apolo y que por ello la castigó: "Me dio el don pero me dijo que nadie, nunca, me creería una palabra" (p. 7).

9 "Hermano [a Cassandra]: ¿Por qué diste mi nombre? ¿Por qué el mío? Pudiste dar el de viejos compañeros de curso, amantes ingratos, algún otro idiota. ¿Por qué el mío? Yo no era una mala persona. [...] ¿Sabes cómo me encontraron? Dormido, abrazado al fusil, sin balas. En un entretecho. Siguieron mi huella. Mi nombre en tu boca" (p. 16).
} 
Generalmente, en los textos contemporáneos la reelaboración de este personaje suele forjarse a partir de una doble alteridad: "la discriminación e instrumentalización a la que se ven sometidas las mujeres por parte de los varones" (Vilches 2005: 44) y la situación de marginalidad que cada dramaturgo se proponga denunciar. Este personaje femenino permite a De la Parra denunciar la doble represión a la que se veían sometidas las mujeres en los campos de detención: la tortura que tienen como fin el derrumbe subjetivo y las agresiones sexuales por parte de los militares.

Sin embargo, es más que esto, es una colaboradora, cuyo sufrimiento ha sido instrumentalizado por los militares para obtener información a favor de su causa. Debemos entender este colaboracionismo como respuesta a la alta dosis de violencia a la que se ve expuesta, es la expresión exacerbada de sumisión y pasividad frente a los deseos y órdenes de los hombres (Jelin, 2002: 101), que, en este caso, son sus victimarios.

El acto de delación sitúa al personaje a medio camino entre las categorías de víctima y perpetrador, un lugar problemático que plantea preguntas incómodas para la esfera pública: ¿deben ser consideradas víctimas legítimas de la violencia de Estado y, por tanto, beneficiarias de las políticas de reparación? ¿Son responsables de los crímenes que propiciaron y deben tomar parte, por ello, en las consecuencias judiciales promovidas por los movimientos de los derechos humanos? De la Parra cuestiona la condena pública que mayoritariamente les niega el estatuto de víctima de violencia de Estado, que olvida que dicha colaboración se produce "en un contexto de extrema violencia, quiebre total de la voluntad y una estructura de presión, amenaza y chantaje que no se atenuó en ningún momento" (Peris, 2019: 158). Esta obra permite al espectador reflexionar acerca de que ella "no es simplemente una puta traicionera sino que las cosas son más complicadas que esto" (Aelbrecht, 2016: 42).

La mayoría de las producciones abordan el tema de la colaboración desde una perspectiva muy misógina que reactiva viejos tópicos patriarcales como caracterizarlas como "putas10" o el viejo dicho de que "las mujeres no saben callar" (Peris, 2019: 158). Exploran las relaciones de dependencia emocional y sentimental que algunas tuvieron con sus superiores del DINA, para ejercer sobre ellas una condena moral. Sin embargo, en los últimos años, se ha incrementado el uso de este tópico como símbolo de la postdictadura y transición chilena. La figura de la colaboradora funciona como un espacio vacío que se resemantiza constantemente desde la ficción para proyectar y construir "los más diversos sentidos sobre la naturaleza de la dictadura y de la violencia de estado" (Peris, 2019: 174), se ha convertido, pues, en un espacio de disputa cultural. En nuestro caso, a través de la evolución subjetiva de Cassandra se evidencia la continuidad existente entre dictadura y sistema democrático a partir de la reproductibilidad del sistema económico neoliberal.

\footnotetext{
${ }^{10}$ Longoni (2006: 150) señala el continuo deslizamiento que se produce de la categoría de traidora a puta. Esta concepción de la colaboradora como puta recorre el imaginario social del hemisferio sur y es atribuida exclusivamente a las mujeres, nunca a los hombres, "cuya traición tiene siempre un signo de conversión ideológica o moral, pero no de entrega o sometimiento sexual" (Longoni, 2006: 152).
} 


\subsection{AGAMENON: REELABORACIÓN MÍTICA DEL PODER MILITAR}

Entre los militares que implantaron dicho sistema neoliberal destaca la figura de Agamenon. Este ha sido identificado por algunos estudiosos con Pinochet, aunque consideramos que es traspasable a otros dictadores cercanos temporal y geográficamente. En su caracterización convergen: masculinidad, dominación y agresividad, es decir, las características que la mayoría de las representaciones atribuye a la identidad militar (Jelin, 2002: 101). En la actualización de esta figura mítica aparecen, además, algunos rasgos negativos que ya recorrían la épica griega: el uso erróneo del poder y la negativa a reconocer y reparar sus abusos de autoridad.

Agamenón, rey por excelencia de la épica griega, era un personaje ambiguo en la Antigüedad, reunía cualidades tanto positivas como negativas. Se movía en la frontera entre la virtud y la desmesura: obedecía los mandatos divinos, pero traspasando los límites de la prudencia. En sus intervenciones se mostraba como un ser soberbio y orgulloso de sus actos, como un ente superior al que nada podía ocurrirle. Se dejó llevar por la ambición de riquezas y la constante necesidad de reafirmarse como el líder de la expedición bélica. Sus actuaciones rebelan una tendencia a tomar el camino erróneo y trasgredir el orden justo de las cosas. Desde la Ilíada es caracterizado por su ybris, por llevar a cabo acciones que van más allá de lo permitido a los seres humanos. Esta desmesura se muestra en su abuso de poder: algunos de los ejemplos más conocidos son el sacrificio de su hija Ifigenia y la toma de Troya ${ }^{11}$.

Esquilo nos legó el primer testimonio de un uso político del personaje de Agamenón, explotando la vertiente más negativa que había sido ya apuntada en la épica. El tragediógrafo a lo largo de su Agamenón puso de relieve que el triunfo del caudillo se asentó sobre actos desmesurados que traspasaban los límites de la prudencia, lo presentó como un personaje malvado y despiadado. Esta configuración negativa casaba con su propósito de mostrar a sus conciudadanos cuán nociva era la influencia de la aristocracia para la polis: mediante el personaje de Agamenón atacó el partido aristocrático, que reclamaba la vuelta a un sistema de gobierno basado en los lazos de sangre, y defendió la democracia. Con la Orestíada, Esquilo pretendía mostrar la imposible convivencia de una justicia colectiva con una tiranía: para el advenimiento de una polis democrática era necesario que la tiranía, encarnada en el héroe trágico, fuese expulsada (Gallego, 1999: 211).

En La puta madre, se actualizan muchos de estos rasgos negativos. La obcecación impide al militar respetar los límites. Con el golpe de estado toma el camino erróneo y transgrede el orden justo de las cosas. En esta obra, los crímenes atroces cometidos en la literatura griega (sacrificio de Ifigenia, toma de Troya) se reescriben como crímenes de lesa humanidad, como atentados contra los derechos humanos. La reclusión en centros clandestinos, la tortura y la desaparición

\footnotetext{
${ }^{11}$ En el primer caso, aludió al "yugo de la necesidad" para justificar su crimen: sacrificó a su hija Ifigenia en aras de la expedición, para conseguir que soplaran los vientos en Áulide y las naves pudieran continuar el camino a Troya. Sin embargo, lejos de actuar en favor del bien común lo hizo movido por la ambición, no le importó derramar sangre inocente de su hija para mantenerse al frente de la expedición. Otro motivo que oscurecía la figura de Agamenón fue el modo tan impío en que llevó a cabo la toma de Troya. Agamenón no fue castigado, a su regreso, con la muerte por haber capitaneado una expedición injusta sino por haber olvidado la tekné polemiké, el arte de hacer la guerra. No respetó estos preceptos y obró de manera inadecuada: destrozó los templos y estatuas de los dioses, atentado que suponía una impiedad contra la esfera divina.
} 
forzada serán los nuevos delitos que se le imputan, que van más allá de lo permitido socialmente, del pacto de ciudadanía sobre el que se asienta el Estado moderno. No obstante, como sus predecesores míticos, el caudillo se muestra soberbio y orgulloso, convencido de haber actuado como debía: "AGAMENON: así empiezan todas las tragedias. La honra, la venganza. Es mejor ser un soldado a sueldo. Yo lo fui. Cumplía con mi deber, ¿me entiendes?” (2006: 15).

El militar encarna el papel de salvador frente al caos que amenazaba traer consigo el socialismo. Esta postura fue muy extendida entre los dictadores del Cono Sur, que construyeron un marco discursivo en el que la representación del pasado como caos les legitimaba como salvadores de una nación en riesgo. Este marco interpretativo, que Stern define como la "memoria como salvación" (Stern12, 2000: 5) pone especial énfasis en el periodo anterior a la dictadura (años 1970-1973, en nuestra obra se corresponde con el triunfo de la Revolución social), cuando la economía iba a abocar al país a una inminente situación catastrófica. Esta lectura del pasado fue impulsada por el entorno militar tras el golpe de estado, no tanto para justificarlo, sino para legitimar el gobierno dictatorial que habían implantado. Así pues, claramente la figura de Agamenon recoge atributos y elementos discursivos que caracterizan a la clase militar chilena, responsable de la dictadura.

\subsection{LA AUSENCIA DE ORESTES COMO AUSENCIA DE JUSTICIA}

Desviándose de largos siglos de tradición, de la Parra reescribe la leyenda de los Atridas y altera su desenlace, mostrando que, tal como sucede con el mito clásico, no existe una versión definitiva ni unívoca de la memoria, sino que esta puede modificarse y rearticularse. El asesinato de Agamenon no tendrá lugar en esta obra, se produce en la mente de Clitemnestra únicamente ${ }^{13}$. El homicidio no llega a producirse, la cadena de ejecuciones es aquí sustituida por un matrimonio de conveniencia. Ya no se disputan el trono o la regencia, como sucedía en la Antigüedad, sino que ambos comparten el capital económico amasado. La descendencia de esta pareja no tendrá ningún peso sobre el desenlace de la obra: no siendo asesinado el padre, no hay ningún crimen que lamentar ni vengar. Como adelanta el mismo autor, no hay Orestes ${ }^{14}$.

¿Cómo podemos interpretar la ausencia de Orestes, la desactivación del motivo de la venganza, la alteración del desenlace? Con el final de la Orestíada asistimos al nacimiento de una justicia colectiva dispensada por la polis mediante tribunales, al triunfo de la justicia colectiva sobre la tiranía. La dramatización de este primer juicio legendario tendría como motivo perpetrar la imposibilidad de que un individuo impusiese su voluntad particular por encima de la voluntad general de la comunidad (Gallego, 1999: 185). La ausencia de Orestes en De la Parra es equiparable a la ausencia de justicia en el nuevo Chile democrático. Se ha erradicado el deseo de venganza de los hijos de las víctimas de la violencia estatal mediante el olvido, con la imposición

\footnotetext{
12 Stern (2000) propuso su propia clasificación de memorias emblemáticas, entendidas como marcos interpretativos bajo los que se agrupan memorias concretas y los sentidos que dan a los hechos vividos. Distinguió cuatro modos de entender la violencia estatal y la violación de los derechos humanos. Estas cuatro memorias toman cuerpo en los distintos personajes y de este modo la pugna entre memorias se traslada al escenario teatral.

13 “CLitemnestra [a Agamenon]: Te he matado varias veces en mis recuerdos. Tengo un amante" (2006: 11).

14 Orestes asesinó a su madre para hacer justicia en nombre del padre. La diosa Atenea, cansada de estas cadenas de crímenes que exigían sangre por sangre, fundó el tribunal del Areópago para que los atenienses administrasen justicia democráticamente mediante el voto.
} 
del consumismo como aspiración inmediata se ha bloqueado todo intento de justicia. En esta nueva sociedad chilena no hay sitio para Orestes: no hay lugar para la creación de tribunales capacitados para castigar los crímenes que atentaron contra los derechos humanos durante el régimen militar.

\subsection{El PADRE: EXILIO POLÍTICO Y RECONVERSIÓN IDEOLÓGICA}

El Padre de Cassandra, a diferencia del resto de su familia, consigue ponerse a salvo, huye del país. Encarna, pues, la figura del exiliado político. Al principio está muy unido a la causa socialista, sin embargo, ante el avance del enemigo se amilana y comienza a retroceder respecto a sus ideales. Esto le vale el duro reproche de su hijo: "Hermano: No te reconozco. Te has vuelto un cobarde. ¿Ya no piensas en el obrero, el campesino? Ya no te sale fuego por la boca. Tiritas, tiemblas" (2006: 13).

Tras los bombardeos, los familiares dan por muerto al Padre, sin embargo, en la escena 16 reaparece y tenemos noticia de su huida a Berlín y su estancia en Caracas. Una vez pasado el tiempo, ya no teme ser perseguido y regresa. Como le sucede a Cassandra, el personaje sufre una evolución psicológica e ideológica: pasa a ingresar las filas de los políticos e intelectuales que se convirtieron en liberales-socialistas. Con la transición su discurso varió hacia un nuevo campo cultural, estos políticos dejaron atrás las promesas de reestructuración social para dar la bienvenida a la "cultura económica moderna", que tenía como base la mercantilización y competitividad (Moulian, 1997: 42). Para gran parte de los políticos, convivir con sus perseguidores y responsables de asesinatos masivos dejó de suponer un problema moral: "se hizo común el intercambio de sonrisas, luego de gestos amistosos, de conversaciones, de fotos en los diarios compartiendo vida social" (Moulian, 1997: 64). El mismo Agamenon, explica a Cassandra el trato amistoso que ahora le dispensa su padre, antiguo militante socialista:

AgAmENON: Ellos han aprendido la lección. Están más mansos. Tu padre, por ejemplo, es todo un caballero. Esta mañana nos hemos saludado como viejos camaradas. Me preguntó por ti. Nos han tomado muchas fotografías. (2006: 27)

Este diálogo tiene lugar en la escena 20, mientras el elenco de personajes posa para una foto conjunta. Esta es la imagen de la reconciliación impulsada por el gobierno democrático, por las nuevas políticas que abogaban por el perdón entre ciudadanos para evitar la polarización de la sociedad. Sin embargo, esta estampa no es tan idílica como el gobierno pretendía hacer parecer, allí falta el Hermano de Cassandra, cuyo paradero es todavía desconocido para los familiares.

\subsection{El HERMANO Y LA MADRE: LAS VÍCTIMAS DE LA DESAPARICIÓN FORZADA}

El Hermano, junto con Cassandra, es uno de los personajes más polémicos de la obra. Pese a las premoniciones de esta y los consejos de su padre no se retiró de la lucha armada y acabó 
recluido en un centro de detenidos-desaparecidos ${ }^{15}$. Su nombre forma parte de la larga lista que su hermana entregó a los militares. Allí, pasado un tiempo le dieron muerte. Ahora únicamente se acuerda de él la Madre:

NiÑO: ¿Madre? ¿Es cierto que nací a la orilla del río mientras buscabas el cuerpo de tu hermano? ¿O es una leyenda mal parida del fantasma de mi abuela?

CASSANDRA: Tu abuela está loca como un pino de pascua. Cree que va a volver si pregunta por él.

MADRE: ¿Dónde está?

CASSANDRA: Mansa preguntita. Vieja loca.

El personaje del Hermano nos permite conectar con uno de los temas más delicados y susceptible de turbar el orden democrático: los detenidos-desaparecidos, categoría particular de aquellos presos cuya muerte se escondió a los otros detenidos y tampoco se notificó a sus familiares. Esta desaparición planificada supuso, no solo la herramienta ideal para la eliminación de cuerpos, pruebas y delitos, sino que también funcionó como técnica intimidatoria para la población restante, sea cual fuere su relación con la esfera política (Castro, 2010: 43). Supuso una técnica coercitiva fundada en la ocultación de los cuerpos asesinados que permite, también, a largo plazo, la desestructuración de redes sociales políticas: neutraliza grupos políticos activos y disuade la formación de una nueva oposición.

La escenificación del detenido-desaparecido en esta obra es relevante por diversos motivos. Se produce en un momento en que las políticas del gobierno instaban a olvidar este asunto y dejarlo fuera de los productos culturales, como si de este modo pudiesen borrarse los conflictos del pasado. De la Parra se enfrenta a la memoria dominante al dar cuerpo en su obra a este grupo social que era negado por los militares, su iniciativa se suma a aquellas que se proponen inscribir la figura del detenido-desaparecido en el imaginario chileno. Emplea el espacio teatral para legitimar a estos desaparecidos como víctimas del gobierno militar gracias a la capacidad de representación de la literatura, en un momento en que se pretende hacer pasar por inexistente aquello que no se representa, que queda fuera de la agenda pública y política.

Sin embargo, como sucede a los artistas de los distintos ámbitos, De la Parra debe enfrentarse a la pregunta de cómo representar al que ya no está, cómo darle un espacio, un cuerpo, una voz. ¿Cómo escenificar la ausencia? El Hermano reaparece en la obra tras morir, y lo hace en calidad de fantasma, para contarnos su historia, su muerte en el campo de detención clandestino. Esta espectral aparición nos ha hecho pensar en el prólogo de Hécuba (424 a. de. C., Eurípides), donde el fantasma de Polidoro, hermano de la princesa Casandra, se persona para contar su desgracia: muerto a manos de su huésped, su cuerpo ha vagado insepulto por el mar, sin ser llorado, sin tumba.

Salvando todas las diferencias que separan a Polidoro del Hermano, queremos señalar que De la Parra retoma la extendida tradición en la literatura clásica de hacer aparecer los espíritus de

\footnotetext{
15 Hablamos de detenido-desaparecido "cuando se produce la privación de la libertad de una persona por parte de Agentes del Estado o personas o grupos de personas que actúan con su autorización, apoyo o aquiescencia, seguida de la falta de información sobre su suerte, su destino o paradero" (Corporación Nacional de Reparación y Reconciliación, 1996).
} 
aquellos que no habían recibido las honras fúnebres ${ }^{16}$ para dar cuerpo a los no-vivos, a los desaparecidos que yacen insepultos en parajes desconocidos. En un momento en que el pasado se invisibilizaba tras un teatro que apostaba por la deshistorización de su contenido y unas políticas de la memoria que priorizaban la museificación sobre el ejercicio de la justicia y el reconocimiento de las víctimas del período dictatorial (Núñez, 2013: 58), De la Parra hace su particular inscripción del detenido-desaparecido en el espacio teatral. La reaparición de este detenido-desaparecido tiene como fin dar la vuelta a las políticas de la Concertación: el Hermano ayuda a construir una memoria del pasado reciente (Aelbrecht, 2012: 43), una memoria entendida como una prueba de la consecuencia con sus valores, identidades o compromisos positivos, éticos y democráticos (Stern, 2000: 5).

Sin embargo, el actor político que era desaparecido no fue la única víctima de esta técnica represiva. Su entorno más próximo se convertía en víctima indirecta también. El núcleo familiar sufrió durante décadas bajo el peso de estos crímenes gubernamentales, por no saber si sus seres queridos están vivos en condiciones inhumanas o muertos y enterrados en fosas comunes (Gatti, 2011: 212). De este modo, el ejercicio de poder se extendió a círculos más íntimos, instaurando la duda, el miedo, la desesperanza en los espacios privados sin que los agentes del Estado tuviesen que intervenir en ellos. En este segundo grupo de víctimas dolientes podemos integrar el personaje de la Madre, cuya pregunta (“¿Dónde está?”), nos dirige hacia la Agrupación de Familiares de Detenidos Desaparecidos ${ }^{17}$.

El personaje de la Madre se construye en torno a la memoria como una ruptura lacerante no resuelta, común en aquellas personas a las que el dolor privó de todo sentido a su vida cotidiana (Stern, 2000: 5), funciona como un referente social convincente que permita al espectador identificarse con ella, con su dolor, que pueda movilizar y hacer reflexionar al receptor (Stern, 2000: 9). Su caso es similar al de muchas mujeres que, pese a no ser encerradas en los CDD, se convirtieron igualmente en víctimas de la violencia estatal: "al tomar como rehenes a los hombres, el sistema represivo afectó a las mujeres en su rol familiar y de parentesco, es decir, en el núcleo de sus identidades tradicionales de mujer y esposa” (Jelin, 2002: 104). Esto les obligó a desempeñaron un nuevo rol bajo la dictadura, a movilizarse para crear y fundar organizaciones que lucharan por los derechos humanos. Las mujeres, de este modo, se convirtieron en portadoras de la memoria social de las violaciones de los derechos humanos.

\footnotetext{
16 Son múltiples los ejemplos en las literaturas griegas y latinas en las que el fantasma de algún muerto insepulto aparece para reclamar sus honras fúnebres, algunos de ellos, incluso, para rebelar el paradero desconocido de su cuerpo. La insepultura de los cuerpos, según las creencias, no les permitía ingresar en el más allá, dejándoles en un lugar liminal en el que no eran ni vivos ni muertos, como les sucede a los detenidos-desaparecidos. La no sepultura de los cuerpos o la falta de ceremonia fúnebre era un hecho que ya turbaba y preocupaba a la sociedad griega y perdura hasta día de hoy, como demuestra la problemática de las fosas comunas o los detenidos desaparecidos.

17 En 1975 los familiares irrumpen en el espacio político, bajo la condición de "familiares de desaparecidos", nace la AFDD. Bajo la pregunta de “¿dónde están?” reclaman la verdad, justicia y memoria que se les ha privado tanto a ellos como a sus allegados. Consideran que su drama no es privado, sino que adquiere una dimensión nacional, por ello, su lucha "fue llevada a cabo independientemente del hecho de que éramos familiares de desaparecidos: éramos chilenos y no queríamos que en Chile las atrocidades que conocíamos siguieran ocurriendo" (intervención de Sola Sierra, recuperado de Castro, 2010: 103). Esta agrupación de familiares se convierte en actor político en cuanto a qué se moviliza en el espacio público, pero sin pretender formar un partido político ni asegurar la persistencia del proyecto social, económico, político defendido por sus desaparecidos.
} 
Hasta aquí el análisis de los personajes nos ha permitido constatar que "también el poder que se ejerce y ejercita en la represión directa se da en el marco de relaciones de género" (Jelin, 2002: 99-115). Las mujeres quedan al margen de la esfera política, sus decisiones, sus actos, no influyen en el devenir político ni social del país. Todos los personajes masculinos son activistas políticos, sus acciones pueden ocasionar transformaciones sociales: el Padre y Hermano combaten por la causa socialista mediante la revolución, Agamenon es uno de los militares que ejecutaron el golpe de estado. Sin embargo, existe un personaje que, debido a su ambigua identidad sexual queda al margen de esta división de géneros planteada por Jelin. Se trata de el Niño, cuya configuración exploraremos a continuación.

\subsection{El NiÑO COMO POSIBILIDAD DE ARTICULAR UNA MEMORIA DE LA CATÁSTROFE}

El Niño, como ya se ha comentado, es un personaje liminal, cuya apariencia transita entre lo masculino y lo femenino. Al inicio de la obra este se encuentra en un camerino "pintándose las uñas de los pies. Durante la obra irá avanzando en un paulatino travestismo, como pasando de la puerilidad a la apariencia femenina sin tránsito por virilidad alguna" (2006: 1). Proponemos equiparar el caso del niño al "travestismo de la democracia" denunciado por Moulian: ese proceso gestado durante la dictadura que permitía la continuación de las estructuras básicas bajo la apariencia de una democracia (1997: 212). Esta es una de las diversas metáforas que emplea De la Parra a lo largo de la obra para evidenciar ante el espectador o lector la continuidad existente entre dictadura y democracia gracias a la reproductibilidad del sistema económico que implantaron los militares.

El Niño da voz a las generaciones posteriores que crecieron bajo el pacto de consenso y olvido sobre el que se refundó la democracia chilena. A estos jóvenes, en muchos casos, se les negó la intrahistoria familiar y, como el Niño, se vieron obligados a preguntar por sus orígenes. Este conocimiento de los acontecimientos pasados era visto con temor por la clase gobernante, el deber de memoria ponía en peligro la estabilidad política y social. Agamenon sugiere a Cassandra que renuncie a tener al hijo por temor a que incube la venganza y ponga fin a los pactos conciliatorios de silencio y olvido:

AgAmenon: Incubará la venganza. Es peligroso. Lo mirarás extraño desde su nacimiento. Se sentirá un forastero en su propia tierra. ¿Crees que necesitamos jóvenes como él? Necesitaremos olvido, homenajes hitos históricos, amnésicos. (2006: 14)

En esta obra, el Niño (y por extensión, las generaciones venideras) encarna la posibilidad de mantener una memoria de lo sucedido (Pinochet, 2012: 155). Las continuas preguntas del Niño acerca del pasado familiar son el punto de partida para reelaborar la memoria, para poder construir un sentido al pasado y forjarse una identidad propia, que, hasta ese momento, le ha sido negada.

Clitemnestra y Egisto, representantes de la nueva sociedad de consumo, se ofrecen a ser los managers que lleven a este Niño al estrellato, a darle un nombre artístico, a construirle una identidad que puedan mercantilizar y vender. El Niño consigue convertirse en una estrella de rock de sexo indefinido con una posición destacada dentro del panorama nacional y el mundo del faranduleo, pese a ello, sigue obstinado en conocer sus orígenes y el pasado familiar. Se construye, 
de nuevo, a partir de una posición liminal: oscila entre el deseo de consumo y el deseo de saber, entre el olvido y la memoria.

Como en toda buena tragedia, no puede faltar, hacia el final, la irrupción de un deus ex macchina, la aparición de un dios en escena. En la Antigüedad este era un recurso muy socorrido para poner fin a aquellos entuertos que los humanos no eran capaces de resolver motu proprio. En este caso, Apolo se persona ante el Niño y le ofrece un don que le permitirá conocer no solo el futuro sino también el pasado. Esto último hace el don especialmente valioso ya que le daría acceso al conocimiento del pasado nacional y la intrahistoria familiar que le han sido negados. La oferta de Apolo representa aquí la posibilidad para las nuevas generaciones de abrir la caja del olvido, de conocer los acontecimientos y articular una nueva memoria que incluya experiencias que excedían la versión oficial de la Historia. Apolo le dispensa la posibilidad de ver, de saber. Sin embargo, como le sucedió a su madre, lleva aparejada una maldición: cuando el Niño se decida a hablar sobre el pasado, lo hará en sentido figurado y lo tomarán por artista:

APOLO: Te daré el don pero sólo podrás hablar en sentido figurado y dirán que eres un artista.

NiÑO: Hablaré

APOLO: Y no te escucharán.

NiÑO: Hablaré.

APOLO: Y no te escucharán. (2006: 28)

Esta escena que cierra la obra alude a la capacidad del arte para dar voz y forma, desde un lenguaje simbólico, a los horrores del pasado, a moldear representaciones de la historia reciente. Esta obra no niega a las generaciones venideras, sumidas en una sociedad de consumo, la posibilidad de articular una memoria, pone de relieve la necesidad de crear un nuevo lenguaje apropiado para dar cuenta de los hechos sucedidos. Estos lenguajes de carácter oblicuo y simbólico sustituyeron al lenguaje convencional, incapaz de hablar de los horrores cometidos. La sociedad chilena todavía no estaba preparada ni disponía de herramientas para repensar su propio pasado sino a través de estos lenguajes quebrados que cifraban de un modo elusivo y tangencial el horror de la dictadura militar. Pero esta metaforización del lenguaje también tiene su contrapartida, puede restar eficacia al mensaje al ser identificado como arte carente de reflexión social, tal y como advierte Apolo que le sucederá al Niño cuando se decida a hablar.

\section{CONCLUSIONES}

Desde los estudios de tradición clásica se ha destacado el uso del mito grecolatino en contextos autoritarios y dictatoriales para hablar, de manera oblicua y velada, de aquella realidad que les estaba vetada. En estos periodos se recurre a él como código estético que permite dar forma a verdades inefables. Sin embargo, en este trabajo hemos querido plantearnos por qué proyecta De la Parra la historia chilena en el mito clásico una vez terminada la dictadura.

Tras el sonado fracaso de La muerte y la doncella, que generó el rechazo de sus conciudadanos por verse violentamente reflejados en ella como cómplices del terrorismo militar con su conformismo y silencio, Marco Antonio de la Parra atenúa el impacto (y, evita de este modo incomodar al público) difuminando las coordenadas espacio-temporales en un juego 
intertextual. Las alusiones míticas permiten poner distancia con respecto a la situación vivida y, en lugar de anclarla en Chile, la hacen global, extensible a cualquier país que acabe de dejar atrás un régimen dictatorial o autoritario.

El mito permite en esta obra no solo construir una problemática sobre la memoria (encarnada en los diferentes personajes que hemos ido viendo detalladamente a lo largo de nuestro análisis), sino también reflexionar sobre la destrucción de identidades sociales que la dictadura llevó a cabo, y ser conscientes del agujero que dejó como saldo. En su primera representación, en 1998, puso en escena los procesos de transformación subjetiva y social que la sociedad chilena todavía era incapaz de conceptualizar de un modo claro y definido. Como afirma Hurtado (2000: 44), a veces, el teatro nos ayuda a comprender lo que nuestra mente y cuerpo se resisten a aceptar, presionados por el propio pensamiento social que se niega a considerarlo como posible.

Queremos destacar, pues, la transposición y actualización del mito de los Atridas al contexto social e histórico que hace el autor con la intención de hacer reflexionar al receptor sobre asuntos que habían quedado marginados de los marcos ideológicos y discursivos implantados por la Concertación. Para ello, reelabora el personaje mítico de Cassandra, para visibilizar, mediante la transformación subjetiva de este personaje, la relación existente entre la violencia militar y la creación de una sociedad de consumo. Trae a la luz una verdad enterrada por las políticas de la memoria y su despolitización de la violencia extendida a partir del Informe Rettig. Hace un uso paródico del mito para desnaturalizar creencias sobre las representaciones del pasado, realiza una reescritura "deconstructivamente crítica" (Hutcheon, 1993: 193), lo que implica que a la vez que reescribe el pasado, lo subvierte y lo cuestiona. Quiere evidenciar una verdad que permanece oculta: la relación existente entre la represión militar y la nueva democracia, gracias a la reproductibilidad de un sistema económico basado en el neoliberalismo, algo que sucede no solo en Chile, sino en diversas regiones de América Latina.

Proponemos leer este proceso creativo de reelaboración del mito clásico como un trabajo de la memoria que implica "la transformación simbólica de los sentidos del pasado" (Jelin, 2002: 14). Esta operación de dar sentido al pasado nos conduce a una lectura ejemplar de los hechos, como demandaba Todorov, que sirva como modelo para comprender situaciones semejantes, aunque con agentes, causas y víctimas diferentes. Obedece a un afán de extraer valores y enseñanzas universales asociados al mismo hecho y se opone a la lectura literal que no "sirve de lección o enseñanza para el porvenir" (Baer, 2010: 147). De este modo, de la Parra obedece al deber de memoria que exige, no un simple recuerdo del pasado, sino una conciencia crítica de los hechos para impedir que vuelvan a suceder. 
BIBLIOGRAFÍA

AELBRECHT, Francisca (2016). ¿Cerrar la caja de la memoria o recordar para no repetir? (Tesis doctoral). Universiteit Gent, Gent.

Albornoz, Adolfo. "Marco Antonio de la Parra, tres décadas de teatro, 1975-2006". Acta Literaria 33 (2006): 109-132.

BAER, Alejandro (2010). "La memoria social. Breve guía para perplejos". Zamora, José Antonio (ed.). Memoria - Politica - Justicia. Madrid: Trotta: 131-148.

De la PARRA, Marco Antonio (1997). La mala memoria. Historia personal de Chile contemporáneo. Santiago: Planeta.

De la PARRA, Marco Antonio (2006). La puta madre. Buenos Aires: CELCIT.

FELD, Claudia. "El imposible debate entre víctimas y victimarios: notas sobre las declaraciones televisivas de Miguel Etchecolatz (1997)”, Rubrica Contemporanea 9 (2016): 77-101.

GALlEGO, Julián. "El pensamiento trágico de la política democrática. El acontecimiento de una nueva justicia en la Orestía de Esquilo". Gerión 17 (1999): 179-211.

García Castro, Antonia (2010). La muerte lenta de los desaparecidos en Chile. Santiago: Editorial Cuarto Propio.

GATTI, Gabriel (2011). Identidades desaparecidas. Peleas por el sentido en los mundos de la desaparición forzada. Buenos Aires: Prometeo Libros.

HuALDE, Pilar. "Mito y tragedia griega en la literatura iberoamericana". CFC: Estudios griegos e indoeuropeos 22 (2012): 185-222.

Hurtado, María de la Luz. "Construcción de identidades en la dramatización de la realidad chilena". Latin American Theatre Review 34 (2000): 43-65.

HutCHEON, Linda. “La política de la parodia posmoderna”. Criterios 30 (1993): 187-203.

JELIN, Elisabeht (2002). Los trabajos de la memoria. Madrid: Siglo Veintiuno Editores.

KLEIN, Naomi (2007). The shock doctrine. Toronto: Random House of Canada.

LOngoni, Ana (2006). Traiciones. La figura del traidor en los relatos acerca de los sobrevivientes de la represión. Buenos Aires: Norma.

Moulian, Tomás (1997). Chile Actual. Anatomía de un mito. Santiago: LOM Ediciones.

NúÑEZ, Javiera. "Poéticas de la memoria en el teatro chileno: Prácticas escénicas entre 1973 y 1990”. Acta Sociológica 61 (2013): 37-60.

PALADINI, Ludovica (2007). Teatro y memoria. Los desafíos de la dramaturgia chilena (1973-2006) (Tesis doctoral). Università Ca' Foscari Venezia, Venezia.

PÉreZ-LABOrde, Elga (2010). "A propósito del teatro chileno: Marco Antonio De La Parra y las metáforas de la represión". Revista Cerrados 19 (2019): 47-59. 
Peris BLANES, Jaume (2005). La imposible voz: Memoria y representación de los campos de concentración en Chile: La posición del testigo. Santiago: Editorial Cuarto Propio.

Peris Blanes, Jaume (2008). Historia del testimonio chileno: de las estrategias de denuncia a las políticas de memoria. Valencia: PUV.

Peris Blanes, Jaume. "Usos del testimonio y políticas de la memoria. El caso chileno". Kamchatka. Revista de análisis cultural 6 (2015): 549-581.

PERIS Blanes, Jaume (2019). "Figuras y ficciones de la colaboración en Chile: espacios de ambivalencia entre víctima y pepetrador”. Ferrer, Anacleto, Sánchez-Biosca (eds.). El infierno de los perpetradores. Imágenes, relatos y concepots. Barcelona: Bellaterra: 155-176.

PinOCHET, Maria Viviana (2012). Reescrituras de tragedias griegas en la postdictadura en Chile: Traición y culpa en la copia infeliz del edén neoliberal (Tesis doctoral). Rutgers University, Nueva Jersey.

RicHARD, Nelly (2007). Fracturas de la memoria. Buenos Aires: Siglo Veintiuno Editores.

RojAS, Sergio (2000). "Cuerpo, lenguaje y desaparición”. Richard, Nelly (ed.). Políticas y estéticas de la memoria. Santiago: Editorial Cuarto Propio :177-188.

STERN, Steve (2000). "De la memoria suelta a la memoria emblemática: Hacia el recordar y el olvidar como proceso histórico (Chile, 1973-1998)". Garcés, Mario (ed.). Memoria para un Nuevo Siglo: Chile, Miradas a la segunda Mitad del Siglo XX. Santiago: Ediciones LOM: pp. 11-33.

Todorov, Tzvetan (2000). Los abusos de la memoria. Barcelona: Paidós.

VILCHES, María Francisca (2005). "Identidad y mito en la escena española actual: Casandra como paradigma”. Vilches, María Francisca (ed.). Mitos e identidades en el teatro español contemporáneo. Nueva York: Editions Rodopi. 